\title{
Cluster Based SME Development: Could be an Effective Tool for Industrialization
}

\section{Md. Joynal Abdin*}

Program Officer Planning, Monitoring and Evaluation Wing The SME Foundation, Bangladesh

There are 48 least developed countries (LDCs) in the world. Employment generation, poverty alleviation etc. are the common challenges facing by all the LDCs around the world. They have limitations in terms of technical, managerial, technological and financial resources to overcome the vicious circle of poverty. Industrialization could be a way forward to alleviate poverty in the LDCs. But to be industrialized all the above mentioned resources needs to be deployed adequately in time. But LDCs have limited access to those resources. The small and medium enterprises (SMEs) are the backbone of industrialization in every economy either it's in developed countries or in least developed one. SMEs could be defined with different parameters in different countries. For example; in Bangladesh SMEs are defined as; "In manufacturing sector, small industry will be deemed to comprise enterprises with either the value (replacement cost) of fixed assets excluding land and building between Tk. 5 million and Tk.100 million, or with between 25 and 99 workers," and medium industry will be deemed to comprise enterprises with either the value (replacement cost) of fixed assets excluding land and building between Tk. 100 million and Tk. 300 million, or with between 100 and 250 workers" (National Industrial Policy 2010, Bangladesh). India defined SMEs as, a small enterprise is an enterprise where the investment is more than Rs. 25 lakh but does not exceed Rs. 5 crore; and a medium enterprise where investment is more than Rs. 5 crore but does not exceed Rs. 10 crore (MSMED Act. 2006, India).

In terms of contribution SMEs are generating about $87 \%$ of civilian employment in Bangladesh; about 30\% of GDP growth comes from the SMEs in Bangladesh. SMEs are accounts for about $45 \%$ of the manufacturing output and $40 \%$ of the total exports of India. They are generating about 59 million employments in over 26 million units throughout the country (Annual report of Ministry of MSME 2010-11,
Government of India). Similarly SMEs are playing a significant role in terms of GDP growth, employment generation and poverty alleviation throughout the world.

It is quite difficult to undertake and implement development interventions for scattered located SMEs in any country. Therefore one best option could be cluster based approach for SME development especially at the LDCs. Clusters are defined by various scholars, countries, international organizations and practitioners in different ways. For example; Porter (2003) defines a cluster as a "geographically proximate group of interconnected companies, suppliers, service providers and associated institutions in a particular field, linked by externalities of various types". Considering the socioeconomic condition of Bangladesh SME Cluster is defined as "A Cluster is a concentration of enterprises producing similar products or services and is situated within an adjoining geographical location around $5 \mathrm{~km}$ radius and having common strengths, weaknesses, opportunities and threats".

Generally SME clusters in most of the LDCs are naturally grown based on availability of raw materials, relevant skills, supply chain advantages, markets demands etc. reasons. They are scattered located throughout the country with existing resilience to face adverse condition. Therefore government's little interventions can result in a massive boom in these clusters. Clusters are creasing self-employed entrepreneurs, generating employment for the workers, technicians, managers, and other relevant professionals. Contributing in increasing GDP growth and poverty alleviation of the country. On the other hand due to a particular geographic location it is easy for the government to supply all sorts of industrial utilities into it. So cluster based SME development could be an effective tool for employment generation, poverty alleviation through industrialization of a country.
*Corresponding author: Md Joynal Abdin, Program Officer the SME Foundation, 4 Panthapath Kawran Bazar, Dhaka-1215, Bangladesh, Tel: 88015536767; E-mail: mdjoynal@gmail.com

Received June 02, 2015; Accepted June 09, 2015; Published June 12, 2015

Citation: Abdin J (2015) Cluster Based SME Development: Could be an Effective Tool for Industrialization. J Socialomics 4: e128. doi:10.4172/2167-0358.1000e128

Copyright: (c) 2015 Abdin J. This is an open-access article distributed under the terms of the Creative Commons Attribution License, which permits unrestricted use, distribution, and reproduction in any medium, provided the original author and source are credited. 